\title{
JUDICIALIZING FEDERATIVE POWER
}

\author{
By J. Richard Broughton
}

\begin{abstract}
The federal Constitution is ambiguous about federative power, Locke's description of the power over war and foreign relations. On the one hand, the Constitution is plainly un-Lockean, dividing federative power between Congress and the President and contemplating that they will share responsibility and exercise sometimes competing prerogatives in war and foreign affairs. Yet there is a rich constitutional and political history in America suggesting that the constitutional scheme is more Lockean than at first blush, even if informal and hidden in complexity. This paper responds to two distinct, but related, lines of argument that seek to limit especially the executive's Lockean tendencies regarding federative power: first, that courts should be more involved in reviewing executive exercises of federative power; and second, that the current administration has asserted an unprecedented view of executive authority that compels judicial review as a crucial constitutional check. This paper offers a brief history of judicial review relevant to federative power, recognizing three distinct eras of decisions that have culminated in a prudently circumscribed approach to challenges regarding the constitutional allocation of federative power that enforces the doctrines of nonjusticiability to avoid judicial intervention and permit play in the joints of the Constitution's formal federative power machinery. Still, the war on terror cases foreshadow the possible coming of a new era in which political decisions regarding war and foreign affairs will be subject to much more rigorous judicial scrutiny. This judicialization of federative power, the paper contends, is an unwarranted and dangerous step. Judicializing federative power would be consistent with the current Supreme Court's omnipotent posture toward judicial review generally, but would further marginalize efforts at practical governance by political institutions and undermine the formal constitutional arrangements that characterize their roles in war and foreign affairs. Judicialization would also damage both the un-Lockean balance, which contemplates the exercise of political tools by both Congress and the President when they are competing in matters of war and foreign affairs, and the Lockean executive, who, Article II contemplates, will act with energy to grapple with necessity and to affirmatively defend the Constitution and the Republic.
\end{abstract}




\title{
JUDICIALIZING FEDERATIVE POWER
}

\author{
By J. RICHARD BROUGHTON*
}

\section{INTRODUCTION}

The intellectual origins of federative power account for the beguiling nature of, and approach to, that subject in American constitutional law and history. Federative power is Locke's description of the state's authority concerning "war and peace, leagues and alliances," or external affairs. ${ }^{1}$ Locke identified federative power alongside executive power and legislative power, but placed federative power wholly in the hands of the executive, or a single magistrate who would possess the executive power (which was distinct in Locke's formulation). ${ }^{2}$ He plainly understood the necessities which marked the vicissitudes of foreign affairs, explaining that matters of war and peace could not be directed by "antecedent, standing, positive laws" and must be dealt with through the exercise of prudence and wise judgment. ${ }^{3}$ Despite Locke's influence in the founding

\footnotetext{
* Lecturer in Government, Johns Hopkins University; Attorney, Criminal Division, U.S. Department of Justice, Washington D.C. This paper is based on remarks delivered at the American Political Science Association Annual Meeting on September 2, 2006. I am grateful to the Center for the Study of the Constitution for inviting me to participate in the APSA conference, and to Roger Barrus, David Marion, Karl Walling, and Paul Peterson for their helpful comments on earlier versions of this paper.

The views expressed herein are my own, and do not necessarily reflect the views or policies of the Justice Department, the White House, or any other governmental entity.

1 John Locke, Second Treatise of Government 83 (Thomas P. Reardon, ed., Macmillan Publishing 1952)(1690).

$2 \quad$ Id. at $83-84$.

3 Id. at 83; see also ROGER BARRUS, ET AL., THE DECONSTITUTIONALIZATION OF AMERICA 128 (2004) (explaining Locke and stating that "[s]ince the executive is always in being and exercises the force of the community as part of its domestic duties, it is better positioned than the legislature to exercise the federative power.”).
} 
generation, ${ }^{4}$ it is notable that the Constitution does not adopt his taxonomy. Rather, the Constitution's allocation of power more closely resembles that of Montesquieu, whose understanding of separated and divided powers serves as the fundamental structure for our constitutional scheme. ${ }^{5}$ In this sense, it can be said that we have a kind of intellectually Lockean constitution that is moderated (and much improved) by Montesquieu's formal separation of powers.

Montesquieu identified the executive and legislative powers, but adds a third distinct power, the power of judging. ${ }^{6}$ The federative power, however, disappears as a distinct power in Montesquieu, for he joins domestic and foreign affairs power in the unity of an executive, and gives independence to the judicial power (which he constitutes with juries of the defendant's peers; Locke acknowledged the judicial power but placed judicial power in the legislature). ${ }^{7}$ In Book XI of The Spirit of the Laws, when he introduces the judicial power, Montesquieu says that liberty in a citizen is "that tranquility of spirit which comes from the opinion each one has of his security."8 Perhaps, then, it is no accident that federative power is not expressly and distinctly revealed in Montesquieu's allocation of powers. As Roger Barrus has suggested, perhaps

\footnotetext{
4 See, e.g., JACK N. RAKOVE, ORIGINAL MEANINGS 7 (1996) (noting the influence of Locke and other Enlightenment philosophers upon the making of the Constitution); HARVEY C. MANSFIELD, TAMING THE PRINCE 258 (1993) (hereafter TAMING THE PRINCE) (stating Locke's influence on the American Constitution); ForRest MCDONALd, Novus Ordo SEClORUM 7 (1985) (noting that Locke's political theory was repeated by the Framers); ARTHUR M. SCHLESINGER, JR., THE IMPERIAL PRESIDENCY 8 (1973) ("the Founding Fathers were more influenced by Locke then any other political philosopher").

5 See MANSFIELD, TAMING THE PRINCE, supra note 4, at 290; MCDONALD, supra note 4, at 81-84.

6 See Charles de Secondat, Baron De Montesquieu, The Spirit of the Laws 157 (Anne E. Cohler, et al., trans., Cambridge Univ. Press. 1989) (1748).

$7 \quad$ Id.; Locke, supra note 1 , at 75-82.

$8 \quad$ MONTESQUIEU, supra note 6, at 157.
} 
Montesquieu sensed something dangerous about federative power (at least as Locke had described it) and thus needed to obscure that power in order to give citizens a greater sense of security about their freedom. ${ }^{9}$

In light of these different approaches by two thinkers of significant repute and distinction among the Framers, it is important to ask whether the federal Constitution is intentionally ambiguous about federative power. And when we talk about federative power and the Constitution, it stands to reason that our focus is predominantly upon the distribution of that power among the political branches of our Government. The Framers explicitly rejected Locke's formal allocation of federative power by, instead, distributing powers of war and foreign affairs in both the Congress and the President: the President serves as commander-in-chief, has the power to make treaties, and can appoint ambassadors, ministers, consuls, and other officers to assist him in carrying out foreign policy; ${ }^{10}$ Congress has the power to declare war, grant letters of marque and reprisal, make rules for the armed forces, and provide funding for the military and military operations. $^{11}$

\footnotetext{
$9 \quad$ Roger M. Barrus, Remarks at American Political Science Association Annual Meeting, Panel on "Federative Power and the Constitution" (Sept. 2, 2006); see also BARRUS, ET AL., supra note 3, at 128 (stating that the Framers "hid Locke's advice in complexity.").

$10 \quad$ U.S. CONST. art II, $\S 2$.

11 Id. art. I. My purpose here is not to take a position on which theory of constitutional power is preferable as a normative matter - the so-called Pro-Congress view or the so-called Pro-Executive view. The lietarure on this subject is vast and excellent. See, e.g., BARRUS, ET AL, supra note 3, at 130; LOUIS Fisher, Presidential War Power (1995); Harold HongJu KoH, The National Security COnstitution (1990); John HART Ely, WAR AND Responsibility (1993); Curtis A. Bradley \& Martin S. Flaherty, Executive Power Essentialism and Foreign Affairs, 102 MiCH. L. REV. 545 (2004); John C. Yoo, War and the Constitutional Text, 69 U. CHI. L. REV. 1639 (2002); Michael D. Ramsey, Textualism and War Powers, 69 U. Chi. L. Rev. 1543 (2002); Saikrishna B. Prakash \& Michael D. Ramsey, The Executive Power Over Foreign Affairs, 111 YALE L.J. 231 (2001); John C. Yoo, The Continuation of Politics by Other Means: The Original Understanding of War Powers, 84 CAL. L. REV. 167 (1996) (hereafter Politics by Other Means); Robert F. Turner, War and the Forgotten Executive Power Clause of the Constitution: A Review essay of John Hart Ely's War and Responsibility, 34 VA. J. INT'L L. 903 (1994); J. Gregory Sidak, To Declare War, 41 DukE L.J. 27 (1991); Robert H. Bork, Erosion of the President's Power in Foreign
} 
But though the Constitution's formal division of power appears to be more Montesquieu than Locke, and though the federative power (while less obscure than in Montesquieu) remains at least ambiguous, the Framers did not entirely agree upon the scope of the powers over war and peace that had been assigned to the two political branches. And there was some sympathy for at least the theoretical basis for Locke's federative regime. Publius, after explaining in Federalist \#70 that energy in the executive is essential to good government, ${ }^{12}$ reminds us in Federalist \#74 that Commander-in-Chief power should obviously belong to the executive because "[o]f all the cares or concerns of government, the direction of war most peculiarly demands those qualities which distinguish the exercise of power by a single hand." ${ }^{\prime 13}$ In the same paragraph, Publius also explains that evidence of the general acceptance of this notion comes from the State Constitutions ${ }^{14}-$ he is right. During the Revolutionary period, virtually all of the State Constitutions placed war-making authority in executive hands, while giving their legislatures control over the state treasuries; only South Carolina's Constitution placed war-making authority in the legislative branch. ${ }^{15}$ And even though the Constitution grants Congress the power to "declare war," the Constitutional Convention, like the antecedent State Constitutions, distinguished "declaring war" from

Affairs, 68 Wash. U. L. Q. 693 (1990); Stephen L. Carter, The Constitutionality of the War Powers Resolution, 70 VA. L. REV. 101 (1984). I confess I am persuaded by Professor John Yoo's recent work on this subject, The Powers of War and Peace, in which he (properly, I think) describes the Constitution's vision of a federative power centralized in an energetic executive, checked by a Congress with distinct powers of funding, declaration, and general legislation. JOHN YOO, THE POWERS OF WAR AND PEACE (2005). That agreement is reflected elsewhere in this article.

12 The FEDERALIST No. 70, at 423 (Clinton Rossiter, ed. 1961) (Alexander Hamilton).

13 THE FEDERAList No. 74, at 447 (Alexander Hamilton).

$14 \quad$ Id.

15 See YoO, supra note 11, at 72. 
"making war." ${ }^{16}$ As John Yoo explains, the primary authorities on war and treaties at the time of the Framing - Grotius, Vattel, and even Blackstone - did not contend that declarations of war were necessary to initiate hostilities; such declarations, rather, served as legal notice to the enemy and to the citizenry that state of war existed. ${ }^{17}$

Later, the dispute over who holds primacy in exercising federative power was best captured in Hamilton and Madison's Helevidius/Pacificus debate concerning President Washington's proclamation of neutrality in the war between England and France. Pacificus, Hamilton's pseudonym, comes closest to the Lockean vision of an executive magistrate holding the federative power. ${ }^{18}$ In foreign relations, Pacificus contends, the executive's power is best capable of responding to the necessities of international intercourse and, moreover, it is whole - as Harvey Mansfield explains, "it acts for a whole in relation to other wholes;",19 while the Constitution admits of exceptions, those exceptions are (and must be construed as) narrow. ${ }^{20}$ Pacificus wants to ensure the preservation of the executive's constitutional prerogatives - among those is to preserve the Union - and that each branch is capable of performing its particular functions. ${ }^{21}$ The debate is notable not merely for its content, but also for Hamilton's singular place in the Founding era and his influence in the development of presidential power. As Karl

16 See 2 RECORDS OF THE FEDERAL CONVENTION OF 1787 at 318-19 (Max Farrand, ed. 1966).

$17 \quad$ See YoO, supra note 11, at 33.

$18 C f$. LoCKE, supra note 1, at 83-84 (stating "these two powers, executive and federative, though they be really distinct in themselves . . . are almost always united. . . . [Federative power] is much less capable to be directed by antecedent, standing, positive laws than the executive").

$19 \quad$ MANSFIELD, supra note 4, at 276.

20 Alexander Hamilton, The First Letter of Pacificus, in THE POWER OF THE PRESIDENCY 53-58 (Robert S. Hirschfield, ed. 1982).

$21 \quad$ Id. at $54-56$ 
Walling explains, President Washington needed a voice, a rhetorical defense of his administration, and that voice was Hamilton. ${ }^{22}$ Thus if we want to understand the origins and development of the American executive we must understand Hamilton, and Hamilton's Pacificus offers a quintessentially robust perspective on the executive's federative powers in the American constitutional scheme. One senses that as Pacificus, Hamilton's conception of the federative power seeks to embrace the structural and institutional design of Article II while retaining a kind of Machiavellian authority to meet necessity. ${ }^{23}$ In this sense, perhaps Hamilton embraces a larger purpose of the Constitution, to unit stability and adaptability.

Consequently, Locke's vision of a single magistrate with authority to direct foreign relations through acts of prudence that were not amenable to the precise directives of positive law, finds expression in American constitutional history, theory, and practice, even if not in its purest form. In this sense, we have both an un-Lockean Constitution of federative power - one in which federative power is divided between the legislature and executive, contemplating that they will share responsibility and exercise

\footnotetext{
22 Karl Walling, Remarks at American Political Science Association Annual Meeting, Panel on "Federative Power and the Constitution" (Sept. 2, 2006).

Ron Chernow's excellent biography of Hamilton provides a brief, but useful, examination of the debate, concluding that Pacificus demonstrated Hamilton's "impassioned pragmatism that informed his foreign-policy views." RON CHERNOw, ALEXANDER HAMILTON 442 (2004). Chernow also rightly demonstrates that Madison's response as Helvidius, one instigated by Jefferson, was largely ad hominem, "reflecting deep animosity" and "[i]]n prose more pedestrian than Hamilton's." Id. at 443. Of course, Hamilton had a flair not only for offering persuasive rhetorical defenses of expansive executive power, but also for defending expansive federal powers, more generally. This is evident in his defense of a national bank. See id. at 353-54. Many of Hamilton's arguments for the bank, which he viewed as crucial to his early economic and fiscal programs, were echoed by Daniel Webster when Webster argued McCulloch $v$. Maryland in the Supreme Court. Id. at 355. Chief Justice Marshall's opinion in McCulloch reads, in many respects, like a Hamiltonian vision of federal power. See McCulloch v. Maryland, 17 U.S. (4 Wheat.) 316 (1819).

23 See, e.g., Niccolo Machiaveldi, The Prince 140 (Allan H. Gilbert, trans., Hendricks House 1964) (1532) (explaining that, in conducting military matters, a "wise prince should practice such habits as these, and never stand idle in times of peace, but should strive to make capital of them, to use in adversity, so that when Fortune grows contrary he may be found ready to resist her.").
} 
sometimes competing prerogatives in war and foreign affairs - and a less noticeable Lockean executive, who, though obscured by the complexities of the un-Lockean scheme, will act with energy (and the ingredients that characterize it) to grapple with necessity and to affirmatively defend the Constitution and the Republic. The Lockean traits of the executive are formal, then, but nuanced.

This background is relevant because it provides the context for what may seem an unremarkable proposition: in viewing the allocation of federative power in the Constitution, whether we agree as a normative matter with the distribution that the Constitution contains, overwhelming focus of the academic literature is upon the Congress and the President; it is clear that one branch is largely left out of the dialogue the judiciary. Article III establishes an independent judiciary with, as Publius described it, neither the power of the sword nor the purse. ${ }^{24}$ Yet as unremarkable as this proposition may be, it, too, possesses a degree of nuance and complexity when we consider the appropriate role for the courts in a democratic republic. And just as it has done in a variety of areas of domestic policy, the judiciary is now poised to exert tremendous influence over American foreign policy and war-time decision-making.

I have written elsewhere of the historical treatment of war powers cases in the American courts, before September 11, 2001. ${ }^{25}$ But a new evaluation is warranted. This paper is therefore a reaction and response to two distinct critiques: first, the more general theoretical assertion of several prominent legal scholars like John Ely, Louis Henkin, Harold Koh, and Thomas Franck, who have argued that courts should be more involved

\footnotetext{
24 See THE FEDERALIST No. 78, at 465 (Alexander Hamilton).

25 See J. Richard Broughton, What Is It Good For? War Power, Judicial Review, and Constitutional Deliberation, 54 OKLA. L. REV. 685 (2001) (hereafter War Power).
} 
in assessing the actions of politicians (particularly the President) with regard to federative powers $^{26}$ (Professor Franck has been most forceful, arguing that the rule of law requires courts to actively conduct judicial review of foreign affairs cases, recognizing no judicial difference between foreign and domestic affairs) ${ }^{27}$ and second, the more specific contemporary argument that because, through a variety of foreign policy decisions, President Bush has asserted an unprecedented vision for executive authority, the White House's existing legal position compels judicial review as a crucial check on the Presidency. ${ }^{28}$ This paper contends that an increasingly judicialized federative power is an unwelcome step toward dismantling the important distinction between domestic affairs and foreign affairs, the latter being marked by a harsh form of necessity that requires

26 See Ely, supra note 11, at 54-60; LOUIS HENKIn, CONSTITUTIONALISM, DEMOCRACY, AND Foreign AfFaIRS (1990); KoH, supra note 11, at 134-49; THOMAS M. FranCK, POLITICAL Questions, JUDICIAL ANSWERS 8-9 (1992).

See also FISHER, supra note 11, at 197-99 (urging lawmakers not to try to compel court action); Major Geoffrey S. Corn, Presidential War Power: Do the Courts Offer Any Answers?, 157 MIL. L. REV. 180 (1998) (contending that history establishes an ongoing role for courts in resolving war powers disputes).

27 See FRANCK, supra note 26, at 156-59; but see Anne-Marie Slaughter Burley, Are Foreign Affairs Different?, 106 HARV. L. REV. 1980 (1993) (questioning Professor Franck's failure to distinguish foreign and domestic affairs for judicial review purposes).

28 See, e.g., Michael J. Kelly, Executive Excess v. Judicial Process: American Judicial Responses to the War on Terror, 13 IND. INT'L \& COMP. L. REV. 787, 819 (2003)(arguing that “[ $t$ ]he arrogance of power demonstrated by the Bush Administration in its legal responses to the terrorist attacks suffered by the country on September $11^{\text {th }}, 2001 \ldots$ cannot be allowed to continue unchallenged" and urging greater judicial action); Elizabeth Drew, Power Grab, 53 N.Y. REV. OF BooKS (June 22, 2006), available at http://www.nybooks.com/articles/19092 (stating that the Bush White House has made an "unprecedented reach for power" and his made "claims of extraordinary presidential power"); Jeremy Brecher \& Brendan Smith, Attack Iran, Ignore the Constitution, THE NATION (April 21, 2006), available at http://www.thenation.com/doc/20060508/attack iran (discussing President Bush's "usurpation" of war powers); Senator Dianne Feinstein, Remarks before the Queen's Bench Bar Association (May 29, 2006), available at http://www.feinstein.senate.gov/06releases/r-queens-bench.pdf (explaining the "calculated expansion of power under this President" and referring to "new legal theories" being advocated by the Bush White House).

Cf. The Honorable Gerald E. Rosen, The War on Terrorism in the Courts, 5 CARDOZO PUB. L., POL'Y \& ETHICS J. 101, 111 (2006) (stating "[i]n the end, it is only the Judiciary - with its constitutional grant of independence from the political system - that can be the final gatekeeper of these critical rights at a time such as this."). 
unique criteria for political action. Moreover, I argue, judicializing federative power marginalizes political institutions and the formal constitutional arrangements that characterize their roles in foreign affairs. ${ }^{29}$

\section{WAR POWERS AND JUDICIAL REVIEW, A BRIEF BUT (IMPERFECTLY) ORGANIZED HISTORY}

While it is true that the judicial power extends to cases involving U.S. laws and treaties, and affecting ambassadors, and other public ministers and consuls, ${ }^{30}$ historically American courts understood that questions touching upon war and foreign relations involved a different set of criteria, criteria that did not lend themselves easily to adjudication, particularly constitutional adjudication. Consequently, throughout our history, although American jurisprudence certainly has seen adjudication of cases touching upon international affairs and American foreign policy, courts have been more reluctant to involve themselves in questions about the proper allocation of constitutional war powers. ${ }^{31}$

Over the past four decades, that reluctance has been manifest in the judiciary's application of the doctrines of justiciability - standing, ripeness, mootness, and the prohibition on advisory opinions, all of which are crucial to the formal separation of powers because their application deprives courts of the power to act - and the political

29 In offering this view I want to be clear that when I speak of judicializing federative power, I am for purposes of this project focusing my contentions on cases involving war powers specifically, rather than the entire realm of foreign relations cases that could arise in the civil and criminal justice systems and implicate judicial review (such as treaties and congressional-executive agreements), although some of the same arguments could obtain with regard to other areas of federative power.

$30 \quad$ See U.S. CONST. art III.

31 See Broughton, War Power, supra note 25, at 693-713; FRANCK, supra note 26, at 61-76. 
question doctrine (both in its constitutional state, and its prudential state, either of which also serves a critical function in circumscribing the power of courts).

I therefore identify three general eras of judicial treatment of cases relevant to constitutionally-proscribed war power: the developmental era, in which we see the judiciary beginning to develop its own sense of how it will approach the judicial role, from the days of the early Supreme Court through the Civil War and the Court's decision in the Prize Cases $;{ }^{32}$ the definitional era, which is marked primarily by the Court's decisions in United States v. Curtis-Wright Export Corp. ${ }^{33}$ and Youngstown Sheet \& Tube Co. v. Sawyer, ${ }^{34}$ in which the Court took bolder steps in attempting to define the nature of constitutional powers, and their limits as applied in foreign affairs; and the nonjusticiability era, in which the courts were routinely called upon to determine whether particular executive actions violated the constitutional allocation of war powers, particularly in light of the enactment of the War Powers Resolution in $1973,{ }^{35}$ but where courts regularly used the doctrines of non-justiciability to avoid resolving those claims. I then suggest that, after the Supreme Court's recent war on terror decisions, there is reason to believe that we may be entering a new era in which the courts will judicialize - or play a more active role in policing - political exercises of federative power (and particularly those originating in the executive). I confess that the paucity of judicial review in the war powers arena, particularly in the Nation's early years, makes this taxonomy imperfect

\footnotetext{
$32 \quad 67$ U.S. (2 Black) 635 (1863).

33299 U.S. 304 (1936).

$34 \quad 343$ U.S. 579 (1952).

$35 \quad 50$ U.S.C. $\S \S 1541-1548$ (2005).
} 
and, frankly, awkward. But my desire is to give some historical context and continuity to the prevailing, though now compromised, view of the judicial role in these types of cases.

\section{A. The Developmental Era}

Within the developmental era, some scholars place great emphasis on early cases like Bas v. Tingy, ${ }^{36}$ Talbot v. Seeman, ${ }^{37}$ and Little v. Barreme, ${ }^{38}$ all of which placed the Supreme Court in the middle of controversies arising from the American seizure of foreign ships in the late 1700's and early 1800's. A few scholars contend that these cases provide the earliest affirmation of the judicial role in refereeing disputes over the power to wage war and make foreign policy. ${ }^{39}$ When viewed this way, at a high level of abstraction, it is undeniable that these are significant cases. But viewing them at this level of generality leads one to somewhat overstate their significance. Viewed with a greater degree of circumspection, these early cases merely concerned the domestic and legal effects of existing war, and the rights of individuals as implicated in private lawsuits arising from war-time political action; none of them involved constitutional questions about the allocation or distribution of federative power. ${ }^{40}$ They were, rather, modest forays into the realm of international relations that involved the interpretation and

\footnotetext{
$36 \quad 4$ U.S. (4 Dall.) 37 (1800).

$37 \quad 5$ U.S. (1 Cranch) 1 (1801).

$38 \quad 6$ U.S. (2 Cranch) 170 (1804).

39 See, e.g., ELY, supra note 11, at 55 (explaining that Little is an example of judicial review of war powers controversies); Corn, supra note 26, at 210 (arguing that the Qasi-War cases offer historical evidence that courts can be involved in adjudicating war powers disputes).

$40 \quad$ See Yoo, Politics by Other Means, supra note 11, at 293.
} 
application of federal statutes; they did not set a precedent for more expansive judicial review of inter-branch disputes concerning the exercise of federative power.

Indeed, often overlooked are other early cases that set precedents for a more circumscribed judicial power. ${ }^{41}$ The origin of the Court's doctrine on advisory opinions (a doctrine that serves as an important structural basis for other limits on judicial power, such as the adequate and independent state ground doctrine) emerged from a famous early controversy over federative power: the question of neutrality in the war between England and France. This, of course was the occasion for Pacificus and Helvedius's commentary on the nature and scope of constitutional federative power, but we often forget that Secretary of State Jefferson had asked the Supreme Court to intervene by answering a series of questions concerning President Washington's power to proclaim American neutrality. ${ }^{42}$ Chief Justice Jay sent a letter back to Jefferson, stating that the Court refused to enter the dispute, citing the Constitution's formal separation of powers and the formal role of courts, and saying that the Court would not "extra-judicially" decide upon Jefferson's questions. ${ }^{43}$

Even Marbury v. Madison, ${ }^{44}$ though not a case about federative power specifically, is instructive, for Marbury provides the doctrinal origin of the political

\footnotetext{
$41 \quad$ See, e.g., United States v. The Schooner Peggy, 5 U.S. (1 Cranch) 103 (1801) (deferring to political branches in controversy concerning America's alleged violation of treat with France when it seized ship near Haiti).

See also Ariel N. Lavinbuk, Rethinking Early Judicial Involvement in Foreign Affairs: An Empirical Study of the Court's Docket, 114 YALE L.J. 855 (2005).

42 See Bernard SchWARTZ, A History OF THE SuPREME COURT 25 (1993).

43 See Correspondence of the Justices, Letter from Chief Justice John Jay and the Associate Justices to President Washington, Aug. 8, 1793, in JesSe H. ChOPER, et AL., CONSTitutional LAW $1505\left(9^{\text {th }}\right.$ ed. 2001).

$44 \quad 5$ U.S. (1 Cranch) 137 (1803).
} 
question doctrine. $^{45}$ Indeed, Chief Justice Marshall's Marbury opinion specifically identifies federative power as an area in which the judiciary should avoid interfering with discretionary acts of the President. ${ }^{46}$ As we will see when we consider the contemporary cases, the political question doctrine plays (as it ought to) a critical role in determining whether judicial review is appropriate as to a particular question of constitutional war power. $^{47}$

Consider also the Supreme Court's divided decision in The Prize Cases, ${ }^{48}$ which marks the outer boundary of the developmental era, and in which the Court upheld President Lincoln's order to block southern ports during the Civil War. Again, the Court does not enter the thicket of determining the existence of a war or defining the boundaries of presidential versus congressional action, although this was the first, and perhaps last, case to articulate in a formal holding the nature of presidential war power. Justice Grier's opinion made explicit its deference to the President, recognizing that the level of force to be employed while acting as Commander-in-Chief is a determination that only the President can make. ${ }^{49}$ "Whether the President in fulfilling his duties, as Commander-in-

$45 \quad I d$. at 169-70 ("The province of this court is . . not to enquire how the executive, or executive officers, perform duties in which they have a discretion. Questions, in their nature political, can never be made in this court.").

$46 \quad$ Id. at 166.

47 See infra, Section II.C; see also Jide Nzelibe, The Uniqueness of Foreign Affairs, 89 IowA L. REV. 941, 946-50 (2004) (discussing application of the political question doctrine in foreign affairs cases, from Marbury to the modern era); Abner J. Mikva, The Political Question Revisited: War Powers and the "Zone of Twilight," 76 KY. L.J. 329, 336 (1987) (stating "[o]ver the years, the political question doctrine has had particular resiliency in cases involving foreign policy"); but cf. FRANCK, supra note 26, at 31-44 (discussing, and questioning, the development of the political question doctrine in foreign affairs cases).

For an excellent discussion of the doctrine beyond the foreign affairs realm, see Rachel Barkow, More Supreme Than Court? The Fall of the Political Question Doctrine and the Rise of Judicial Supremacy, 102 CoLUM. L. REV. 237 (2002).

$48 \quad 67$ U.S. (2 Black) 635 (1863).

$49 \quad I d$. at 670. 
Chief, in suppressing an insurrection, has met with such armed hostile resistance, and a civil war of such alarming proportions as will compel him to accord them the character of belligerents," the opinion explained, "is a question to be decided by him, and this court must be governed by the decisions and acts of the political department of the Government to which this power was entrusted." ${ }^{50}$ The Prize Cases thus provide perhaps the most useful paradigm from this era for judicial deference, as opposed to abstention, in war powers controversies.

\section{B. The Definitional Era}

The next era - the definitional era - comes in the twentieth century, where two cases stand out above all others for their influence in determining the nature and scope of constitutional federative powers, although neither case, properly understood, involved the actual adjudication of a constitutional question about the scope of federative power specifically. Indeed, the most famous portions of each case were not, strictly speaking, binding judicial authority: in Curtiss-Wright, Justice Sutherland's notorious discussion of executive supremacy in foreign affairs; and in Youngstown, the Steel Seizure Case, Justice Jackson's concurring opinion establishing what has been adopted as the operative modern constitutional taxonomy of executive power vis-a-vis the Congress.

In Curtiss-Wright, Justice Sutherland, borrowing from an early speech by John Marshall and from Pacificus's description of the executive, ${ }^{51}$ stated that the president is

\footnotetext{
$50 \quad I d$.

5110 ANNALS OF CONG. 163 (1800) (statement of Rep. Marshall); Hamilton, supra note 20, at 54 (describing the executive as the "organ of intercourse between the nation and other nations"); see also Sarah H. Cleveland, The Plenary Power Background of Curtiss-Wright, 70 U. CoLO. L. REV. 1127 (1999)
} 
the "sole organ of the United States in the field of international relations." $52 \mathrm{He}$ also drew the critical distinction between domestic and foreign affairs, and stated that "the President alone has the power to speak or listen as representative of the nation."53 Scholars have, quite properly, noted some of the flaws in Justice Sutherland's CurtissWright opinion, notably his failure to account for congressional foreign relations powers granted specifically by the Constitution and for his discussion of the nature and scope of executive powers over international affairs, despite the fact that this discussion was unnecessary to the Court's resolution of the precise issue in that case, that Congress could constitutionally delegate power to the president to halt arms sales to warring nations in South America. ${ }^{54}$ Sutherland's dicta, however, has proven remarkably resilient despite the scholarly criticism, and is frequently cited by those defenders of a more purely Lockean version of distributing federative power. ${ }^{55}$ Indeed, Curtiss-Wright stands alongside Hamilton's Pacificus essays as an example of the appeal of Lockean federative power theory to the practice of governance in American history.

\footnotetext{
(writing that Curtiss-Wright's plenary executive powers dicta is grounded in late- $19^{\text {th }}$ Century jurisprudence of inherent plenary powers).

52299 U.S. 304,319 (1936).

53 See id.

$54 \quad$ See FISHER, supra note 11, at 57, 61; FRANCK, supra note 26, at 15; KoH, supra note 11, at 94.

55 See Pasquantino v. United States, 544 U.S. 349, 369 (2005) (opinion of Thomas, J.); Hamdi v. Rumsfeld, 542 U.S. 507, 582 (2004) (Thomas, J., dissenting); Goldwater v. Carter, 444 U.S. 996, 1004-05 (1977) (Rehnquist, J., concurring in the judgment); see also American Ins. Ass'n v. Garamendi, 539 U.S. 396, 415 (2003) (citing Curtiss-Wright with approval); Haig v. Agee, 453 U.S. 280, 289 n. 17 (1981) (distinguishing the issue from the one in Curtiss-Wright).

For a good discussion of Curtiss-Wright's historical significance in reshaping foreign affairs law, see G. Edward White, The Transformation of the Constitutional Regime of Foreign Relations, 85 VA. L. REV. 1 (1999).
} 
Moreover, as significant as the Steel Seizure Case has become to assessing separation of powers problems (and Justice Jackson's opinion, though it did not garner a majority of votes, has emerged over time as the dominant rule in this area, as reflected by the Court's decision in, for example, Dames \& Moore v. Regan ${ }^{56}$ ), it is important to recall that Youngstown did not involve federative power, per se, nor is its rule, or Justice Jackson's taxonomy, limited to foreign affairs problems. Nor does Justice Jackson's approach suggest that courts should offer aggressive judicial review even where his categories of power are implicated; rather, Justice Jackson concedes that Congress should use its own institutional tools and political self-help rather than expect assistance from the federal judiciary. ${ }^{57}$ In fact, during this same era, Justice Jackson wrote in Chicago \& Southern Air Lines Inc. v. Waterman S.S. Corp.:

the very nature of executive decisions as to foreign policy is political, not judicial. Such decisions are wholly confided by our Constitution to the political departments of Government, Executive and Legislative. They are delicate, complex, and involve large elements of prophecy. They are and should be undertaken only $b$ those directly responsible to the people whose welfare they advance or imperil. They are decisions of a kind for which the Judiciary has neither aptitude, facilities, nor responsibility and which has long been held to belong in the domain of political power and not subject to judicial intrusion or inquiry. ${ }^{58}$

Curtiss-Wright and Youngstown, then, provide competing definitions of constitutional federative power: whereas Curtiss-Wright defines federative power as implicating national sovereignty and centralized in the executive (per Locke), Youngstown can be

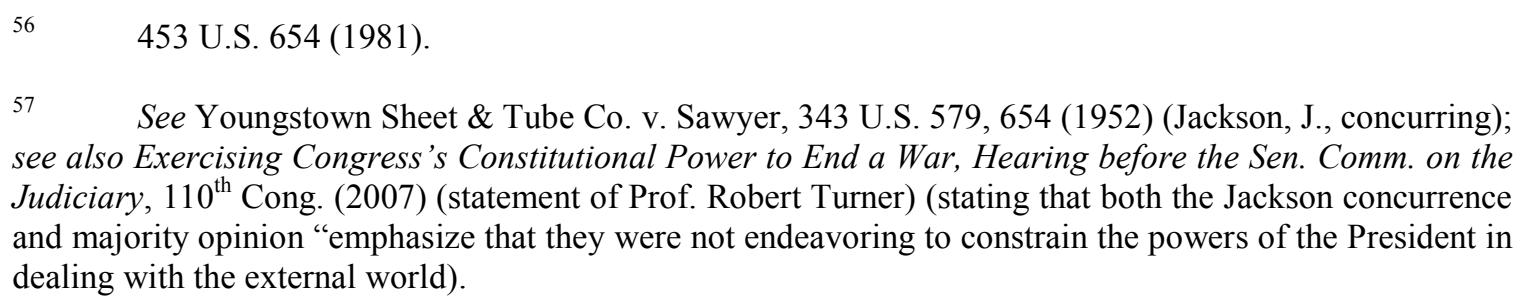
see also Exercising Congress's Constitutional Power to End a War, Hearing before the Sen. Comm. on the Judiciary, $110^{\text {th }}$ Cong. (2007) (statement of Prof. Robert Turner) (stating that both the Jackson concurrence and majority opinion "emphasize that they were not endeavoring to constrain the powers of the President in dealing with the external world). 
applied to limit executive flexibility to deal with the necessities of the international arena.

Yet neither case tells us precisely how active the judicial role should be in policing exercises of constitutional war power. Moreover, Justice Jackson's opinion in Chicago \& Southern Air Lines provides at least a theoretical basis for either judicial abstention or at least for the kind of deference we see in The Prize Cases. So while this era gives us some definition (albeit conflicting ones) of the nature of constitutional powers, it provides only ambiguous guidance as to the scope of judicial power to resolve controversies about the allocation of constitutional war and foreign affairs powers. ${ }^{59}$

\section{The Non-Justiciability Era}

Thus far, our focus has been upon the Supreme Court. By the 1960s, though, armed with the Youngstown precedent, litigants began asking lower courts to decide explicitly whether presidential action had violated the constitutional allocation of federative powers. In addition, a statutory challenge (or, as it became, a constitutional challenge with a statutory overlay) became more palatable, after Congress enacted the War Powers Resolution over President Nixon's veto in $1973 .{ }^{60}$ By this time, however, the Court has also decided Baker v. Carr, ${ }^{61}$ which established the modern framework for

\footnotetext{
59 That ambiguity is reinforced if we look at the Court's approach in another opinion from this era written by Justice Jackson, Johnson v. Eisentrager, 399 U.S. 763 (1950). Eisentrager held that the Court lacked jurisdiction to hear a habeas petition filed by German prisoners held in occupied Germany by American forces. Justice Jackson's opinion there is littered with language of deference to political authorities managing war. $I d$. at 779 . Both the formal holding, and underlying rationale, of Eisentrager, however, have been undermined by Rasul v. Bush, 542 U.S. 466 (2004). See Standards for Military Commissions, Hearing before the House Comm. on Armed Services, $109^{\text {th }}$ Cong. (2006) (statement of Theodore B. Olson) (criticizing Rasul's treatment of Eisentrager).
}

6050 U.S.C. $\S 1541$ et seq. (2005); see also 1973 PUBLIC PAPERS OF THE PRESIDENTS 893 (describing President Nixon's constitutionally-based veto).

61

369 U.S. $186(1962)$. 
applying the political question doctrine. Consequently, despite the appearance that Youngstown provided all of the analysis necessary to judge whether a presidential act of war-making violated the Constitution's distribution of powers, lower courts beginning in the 1960s refused to become entangled in the hotly-debated question of whether a particular presidential decision of war was unconstitutional. ${ }^{62}$ The primary point of departure here is the Vietnam War, and especially President Nixon's orders related to the bombing in Cambodia, which were the subject of many lawsuits in the lower federal courts challenging the president's authority to initiate hostilities in the absence of a congressional declaration of war, but the legal basis for the litigation was adopted with regard to subsequent military operations in the 1980 s and $1990 \mathrm{~s} .{ }^{63}$ No court ever ruled upon the constitutionality of presidential war-making in these cases. Instead, the lower courts used the political question doctrine, and the doctrines of standing, ripeness, and mootness, to dispose of these cases.

In Orlando v. Laird, Massachusetts v. Laird, and Mitchell v. Laird, for example, courts applied various forms of the political question doctrine to avoid ruling on the merits of servicemembers's constitutional challenges to presidential initiation and conduct of hostilities in Vietnam. ${ }^{64}$ Similarly, in DaCosta v. Laird, the Second Circuit applied the doctrine where an Army Specialist stationed in Vietnam questioned whether the President could order mining of Vietnamese ports and harbors. ${ }^{65}$ This trend

62 See Broughton, War Power, supra note 25, at 701-04.

$63 \quad$ See id. at 701-07.

64 Orlando v. Laird, 443 F.2d 1039 (2d. Cir. 1971); Massachusetts v. Laird, 451 F.2d $26\left(1^{\text {st }}\right.$ Cir. 1971); Mitchell v. Laird, 488 F.2d 611 (D.C. Cir. 1973).

$65 \quad 471$ F.2d 1146 (2d Cir. 1973). 
continued in the 1980s and 1990s, where lower courts used the justiciability doctrines to turn away challenges under Article I and the War Powers Resolution to presidential decisions to involve the U.S. in hostilities in El Salvador and Nicaragua (under President Reagan), ${ }^{66}$ the Persian Gulf (under President Reagan and the first President Bush) ${ }^{67}$ and Kosovo (under President Clinton). ${ }^{68}$ The D.C. Circuit's decision in Campbell v. Clinton ${ }^{69}$ which challenged President Clinton's use of airstrikes in Kosovo, also provides a particularly useful discussion between Judges Silberman and Tatel concerning justiciability in war powers cases. Judge Silberman espoused a robust political question doctrine, while Judge Tatel was less sanguine about the doctrine, acknowledging a role for the courts in war powers questions. ${ }^{70}$

Most recently, the First Circuit used the ripeness doctrine to reject a challenge brought by servicemembers, their families, and various Members of Congress - to President Bush's use of military force in Iraq. ${ }^{71}$ Although the court acknowledged that the political question doctrine is "famously murky" and that its reliance on that doctrine has been historically "sparing," it nonetheless concluded that ripeness afforded the clearest and most principled basis for disposing of the lawsuit. ${ }^{72}$ Congress could take

66 See Crockett v. Reagan, 558 F. Supp. 893 (D.D.C. 1982); Sanchez-Espinoza v. Reagan, 770 F.2d 202 (D.C. Cir. 1985).

$67 \quad$ See Lowry v. Reagan, 676 F. Supp. 333, 334 (D.D.C. 1987); Dellums v. Bush, 752 F. Supp. 1141 (D.D.C. 1990); Ange v. Bush, 752 F. Supp. 509 D.D.C. 1990)

68 See Campbell v. Clinton, 203 F.3d 19 (D.C. Cir. 2000).

69 Id; see also Broughton, War Power, supra note 25, at 707-13 (analyzing Campbell).

70 Compare Campbell, 203 F.3d at 24-25 (Silberman, J., concurring), with id. at 37-40 (Tatel, J., concurring).

71 Doe v. Bush, 323 F.3d $133\left(1^{\text {st }}\right.$ Cir. 2003).

$72 I d$. at 140 . 
some immediate action that would affect troop deployment, the Iraqis could act in a manner that would avert further hostilities, investigations by weapons inspectors continued in Iraq - a number of contingencies remained that made the suit premature. ${ }^{73}$ In addition, although not strictly a war powers case, the District Court for the District of Columbia rejected a challenge to President Bush's unilateral withdrawal from the AntiBallistic Missile Treaty. ${ }^{74}$ In this suit, brought exclusively by Members of the House of Representatives (led by Representative Dennis Kucinich, an Ohio Democrat), the court disposed of the matter on both standing and political question grounds. ${ }^{75}$

Although most of the action during this era occurred in the lower courts, the Supreme Court, too, articulated a relatively robust political question doctrine for foreign affairs. First, in Gilligan v. Morgan, ${ }^{76}$ a case arising out of the tragedy at Kent State University, the Court refused to order federal court supervision of National Guard troops, holding instead that making rules for training and discipline of the militia was a power committed exclusively to the Congress under Article I, section 8. And again, a fourJustice plurality invoked the doctrine in Goldwater v. Carter ${ }^{77}$ which, although not a war powers case (it concerned President Carter's unilateral termination of the Mutual Defense

\footnotetext{
$73 \quad$ Id. at 139 .

74 Kucinich v. Bush, 236 F. Supp. $2 d 1$ (D.D.C. 2002).

75 Id. at 6-11, 17; see also Mahorner v. Bush, 224 F. Supp. 2d 48, 49-53 (D.D.C. 2002) (dismissing, on standing and political question grounds, lawsuit challenging Bush Administration policy toward Middle East).

76413 U.S. 1 (1973).

77444 U.S. 996 (1979).
} 
Treaty with Taiwan), provides a useful discussion of federative power distribution, particularly in light of the Curtiss-Wright dicta. ${ }^{78}$

This era thus demonstrates that, although armed with precedent for upsetting presidential war-time decision making on constitutional grounds, the courts acknowledged a prudential sensitivity to their institutional own limits, and helped to effectuate the Constitution's vision of give-and-take, and self-help, among the political branches in exercising foreign affairs power. $^{79}$

\section{An Emerging Era of Judicialization?}

With respect to questions about the constitutional allocation of powers in war powers cases, the model developed in what I have termed the non-justiciability era - in which the doctrines of justiciability, complemented by a prudential sensitivity about the uniqueness of such matters that required judicial deference - still, presumably applies. But model is confounded (or at least potentially so) by the Supreme Court's recent war on terrorism cases.

Three cases are noteworthy in this respect: Hamdi v. Rumsfeld, ${ }^{80}$ which rejected the kind of broad, pro-executive view of constitutional war and foreign affairs powers that has its philosophical origins in Locke, and later in Pacificus and Marshall, and which

78 Id. at 1004-05 (Rehnquist, J., concurring in the judgment).

79 See Broughton, War Power, supra note 25, at 719-24; see also Jonathan L. Entin, The Dog That Rarely Barks: Why Courts Won't Resolve the War Powers Debate, 47 CASE W. RES. L. REV. 1305, 1307-13 (1997) (explaining that "there are various procedural and jurisdictional obstacles to litigating over war and foreign affairs); Sidak, supra note 11, at 114-15 (explaining that even if war powers disputes are justiciable, courts will have difficulty framing a remedy and can use the doctrines of ripeness and mootness to foreclose judicial review); Mikva, supra note 47, at 339 (stating that "if a court wishes to avoid deciding a war powers question, it has the doctrinal tools to do so.").

80

542 U.S. 507 (2004). 
made clear that judicial review in the foreign policy arena would not be circumscribed when the litigation implicates individual rights of an American citizen; Rasul v. Bush, ${ }^{81}$ which held that even non-citizen enemy combatants held outside the jurisdiction of the United States could have the privilege of seeking habeas corpus relief from their detention; and, most recently, Hamdan v. Rumsfeld, ${ }^{82}$ which once again rejected broad assertions of presidential war power and which appears to sanction a judicial approach that places the Court now firmly in the business of judging and adjudicating the details of presidential (or even congressional) decisions regarding war policy. Indeed, the Court now seems to be laying the foundation for a continuing judicial policy of micromanaging war-time decision making by the political branches.

Hamdi and Hamdan are particularly worthy of discussion here, for in each case the Court articulates not simply a role for the judiciary in these matters, but an aggressive, non-deferential, interventionist role. In Hamdi, Justice O'Connor wholly rejects the Government's position that the courts lack the institutional competence to supervise the executive's military decision-making and that the separation of powers mandates a circumscribed role for the courts here. ${ }^{83}$ Although she concedes that she does not address directly the broader question concerning the Court's role in war powers controversies more generally, ${ }^{84}$ Justice O'Connor makes clear that when executive warmaking implicates individual rights, the Constitution envisions a role for all three

\footnotetext{
$51 \quad 542$ U.S. $466(2004)$.

$82 \quad 126$ S.Ct. 2749 (2006).

$83 \quad$ Hamdi, 542 U.S. at 535-36.

$84 \quad$ Id. at 536.
} 
branches. ${ }^{85}$ Indeed, Justice O'Connor's opinion suggests that the result of a more deferential judicial model would be the condensing of power into a single branch. ${ }^{86}$ Still, despite the lack of deference and the Court's aggressive application of due process balancing to the detention of citizen combatants, the plurality is careful to insist that the political branches retain sufficient flexibility to craft procedures that would satisfy Hamdi's due process rights. ${ }^{87}$

Apparently, though, this kind of flexibility still remains subject to the Court's omnipresent watchful eye, as Hamdan illustrates. In the complicated Hamdan decision, a Court majority endorsed three major holdings: that, notwithstanding Congress's attempt in the Detainee Treatment Act to foreclose habeas relief for Guantanamo Bay detainees, courts have jurisdiction over habeas petitions that were filed before the DTA's effective date ${ }^{88}$ that the military commission structure is inconsistent with the UCMJ $;{ }^{89}$ and that Common Article 3 of the Geneva Conventions applies to the conflict with al Qaeda. ${ }^{90}$ Notable in Hamdan is the some of the language the Court uses in questioning the existence of military necessity. ${ }^{91}$ And the majority - neither in Justice Stevens' opinion nor in the separate opinions by Justice Kennedy or Justice Breyer - makes no meaningful effort (unlike the plurality in Hamdi) to reassure us of the Court's sensitivity to the limits

\begin{tabular}{ll}
\hline 85 & $I d$. \\
86 & $I d$. \\
87 & $I d$. at $538-39$. \\
88 & Hamdan, 126 S.Ct. at 2764-69. \\
89 & Id. at $2773-86$. \\
90 & $I d$. at $2793-98$. \\
91 & $I d$. at 2785.
\end{tabular}


on its role generally, and particularly in cases involving war powers and foreign affairs. ${ }^{92}$ Rather, Hamdan subjects the President's contentions to exacting scrutiny, giving no deference whatsoever: it resolves any uncertainty about the DTA against the President; ${ }^{93}$ it assumes that the congressional authorization was not specific enough to justify Hamdan's military commissions, ${ }^{94}$ Justice Stevens even endorses the proposition that Hamdan cannot be prosecuted for conspiracy. ${ }^{95}$ The Court's review in Hamdan looks resembles its application of strict scrutiny in some areas of constitutional law, in which it presumes the unconstitutionality of a law and places the burden on the Government to justify the law by demonstrating that it is narrowly tailored to further a compelling governmental interest. $^{96}$ Of course, strict scrutiny is ordinarily an element of constitutional adjudication, and Hamdan is not a constitutional case; but the aggressive review here, and the lack of deference, suggests that the comparison is a fitting one. No one reasonably expected the Court to defer to presidential prerogatives in the manner of Curtiss-Wright, but the regime of judicial review that Hamdan represents is far from the carefully circumscribed view of the judge's role that Justice Jackson articulated in

92 Justice Kennedy, for example, notes that although the Court can give "some deference" to the President's practicality judgments, a lower degree of deference is afforded here because of the contrast in language that Congress used here. See id. at 2801 (Kennedy, J., concurring in part).
$93 \quad$ Id. at 2769.
$94 \quad$ Id. at 2775 .
$95 \quad$ Id. at $2779-80$.

96 See, e.g., Grutter v. Bollinger, 539 U.S. 306 (2003) (applying strict scrutiny to Equal protection Clause challenge to race-based law school admissions policy); United States v. Playboy Entertainment Group, Inc., 529 U.S. 803 (2000) (applying strict scrutiny to content based regulation of speech); Church of the Lukumi Babalu Aye, Inc. v. City of Hialeah, 508 U.S. 520 (1993) applying strict scrutiny to Free Exercise Clause challenge to city ordinance that was not religion-neutral or generally applicable); Perry Education Ass'n v. Perry Local Educators' Ass'n, 460 U.S. 37 (1983) (applying strict scrutiny in First Amendment challenge). 
Chicago \& Southern Air Lines, and arguably goes beyond the modest role that Justice O'Connor endorsed in Hamdi, which by its terms extended judicial protection during a state of war only to American citizens. ${ }^{97}$

Importantly, neither Hamdi nor Hamdan express a view about the proper allocation of constitutional war power; Hamdan, in fact, issues no constitutional rulings at all (Justice Kennedy's separate concurrence, however, refers to Youngstown and says that this is a case where the President's authority is at its lowest ebb under Justice Jackson's taxonomy). ${ }^{98}$ And in both Hamdi and Hamdan, the Court expressly avoids the more difficult constitutional war powers problem of whether the presidential actions were justified by inherent authority under Article II, because Congress here had authorized the actions. ${ }^{99}$ Moreover, Hamdi, Hamdan, and Rasul all involved habeas litigation, which by definition requires the involvement and review of courts. It is worth considering, however, how the Court would react if Congress had not authorized the actions (a problem the Court would have had to confront in Hamdi had it answered the first question presented differently), or if the questions presented occurred outside the habeas context. It is not difficult to imagine a scenario (it has happened, consider the previous subsection) in which a president of one party engages in military decision-making pursuant to his Article II powers with which a Congress of another party takes issue, prompting litigation. The 110th Congress, in fact, offers another such possibility: emboldened by a new Democratic majority in each house of Congress, and increasing

$97 \quad$ See Hamdi, 542 U.S. at 536, 537 (stating that the Court's holding protected American citizens).

98 Hamdan, 126 S. Ct. at 2800 (Kennedy, J., concurring in the judgment).

$99 \quad$ See Hamdi, 542 U.S. at 517. 
unpopularity of the War in Iraq, the 110th has already seen the introduction of legislation (though some of it in the form of non-binding resolutions) and legislative hearings in which members have questioned an increase in American troop strength and contemplated their own authority to bound President Bush's conduct of the war. ${ }^{100}$

More could be said about these decisions, Hamdan in particular, but it is not my project here to provide a comprehensive comment upon the cases; others have done so, and better than could I. ${ }^{101}$ Rather than belabor the details further in this subsection, I prefer to make an observation concerning Justice Thomas that has gone mostly unnoticed in the recent commentary concerning the Court's war on terror decisions.

Justice Thomas was alone in dissent in Hamdi (Justices Scalia and Stevens also dissented, but on grounds that the Government should have prosecuted Hamdi for treason or suspended the writ of habeas corpus), ${ }^{102}$ and a dissenter in Hamdan and Rasul. He wrote separately in Hamdi and Hamdan, speaking exclusively for himself in Hamdi, and joined only in part by Justices Scalia and Alito in Hamdan. ${ }^{103}$ Through these decisions, it appears as though Justice Thomas has now emerged as the only member of the Court to

100 See, e.g., Sen. Con. Res. 2, $110^{\text {th }}$ Cong. (introduced Jan. 17, 2007) (sponsored by Sen. Biden, expressing a bipartisan resolution in Iraq); S. 121, $110^{\text {th }}$ Cong. (introduced Jan. 4, 2007) (sponsored by Sen. Feingold, providing for redeployment of United States forces from Iraq); S. 433, $110^{\text {th }}$ Congress (introduced Jan. 30, 2007) (sponsored by Sen. Obama, expressing United States policy for Iraq); Exercising Congres's Constitutional Power to End a War, Hearing before the Sen. Comm. on the Judiciary, $110^{\text {th }}$ Cong. (2007); see also Sen. Res. 39, $110^{\text {th }}$ Cong. (introduced Jan. 24, 2007) (sponsored by Sen. Byrd, expressing sense of the Senate that Congress approve any offensive military action by United States against any other nation).

101 See Neal Kumar Katyal, Hamdan v. Rumsfeld: The Legal Academy Goes to Practice, 120 HARV. L. ReV. 65 (2006); Standards for Military Commissions, Hearing before the House Comm. on Armed Services, $109^{\text {th }}$ Cong. (2006) (statements of Theodore B. Olson and Steven G. Bradbury); Hamdan v. Rumsfeld: Establishing a Constitutional Process, Hearing before the Sen. Comm. on the Judiciary, $109^{\text {th }}$ Cong. (2006) (statement of Dean Harold Hongju Koh); Hearing before the Sen. Committee on Armed Services, $109^{\text {th }}$ Cong. (2006) (statement of Attorney General Alberto Gonzales).

See Hamdi, 542 U.S. at 554-579 (Scalia, J., dissenting).

See Hamdan, 126 S. Ct. at 2823 (Thomas, J., dissenting). 
fully embrace a robust regime of judicial deference in cases implicating presidential exercises of war power. His constant citation to The Prize Cases is evidence of this. ${ }^{104}$ He also appears, though not quite as directly as even he might prefer, to champion a robust executive role in exercising federative power, in addition to a highly deferential judicial model for foreign affairs cases. As he explained in Hamdi, "Congress, to be sure, has a substantial and essential role in both foreign affairs and national security. But it is crucial to recognize that judicial interference in these domains destroys the purpose of vesting primary responsibility in a unitary executive." 105 Turning the tables on those who rely upon Justice Jackson's Youngstown opinion, Justice Thomas cites Justice Jackson's opinion in Chicago \& Southern Air Lines ("the very nature of executive decisions as to foreign policy is political, not judicial. Such decisions are wholly confided by our Constitution to the political departments of Government, Executive and Legislative," Justice Thomas reminds us). ${ }^{106}$ Justice Thomas's vision of federative power, then, looks downright Hamiltonian, even Lockean, and sets him apart from each of his colleagues on the Court. ${ }^{107}$

\footnotetext{
104 See id. (Thomas, J., dissenting); Hamdi, 542 U.S. at 581 (Thomas, J., dissenting).

$105 \quad I d$. at 582 (Thomas, J., dissenting).

$106 \quad I d$. (Thomas, J., dissenting).

107 This development furthers my (entirely plausible) belief that, from the perspective of constitutional jurisprudence and particularly taking into account his positions the Commerce Clause arena, Thomas is perhaps the most interesting figure on this Supreme Court.
} 


\section{Against Judicialization}

Having described the historical treatment of foreign affairs in the courts, and the recent trend toward more aggressive judicial review of presidential war-making decisions, a few normative observations are in order. These observations relate not simply to the Court's treatment of foreign affairs, but, more broadly, to its own understanding of its role as an institution in the constitutional design.

My contention is not simply that courts should be more deferential, or, in some instances, entirely uninvolved, in many of these cases, although I adhere to these notions. Scholars like Rachel Barkow ${ }^{108}$ and Jide Nzelibe, ${ }^{109}$ have persuasively advocated a robust political question doctrine and doctrines of deference that ensure the courts will only exercise their ability to act in cases where they are specifically empowered, or otherwise competent, to do so. And in response to those who contend that these cases are within the judicial ken because "this is what judges do," (consider Judge Tatel's concurring opinion in Campbell) those like Justice Thomas respond with a compelling assertion grounded in sensible notions of institutional competence: unlike many cases involving domestic affairs, judges lack sufficient competence, expertise, and facilities to delve too deeply into war powers problems. ${ }^{110}$ In fact, the notion espoused by critics of the

108 See Barkow, supra note 47, at 319-336.

109 See Nzelibe, supra note 47, at 999-1009 (employing "balance of institutional competencies approach, which envisions judicial review of foreign affairs cases along a spectrum that includes cases implicating individual rights and those in which Congress has acted).

110 See Hamdi, 542 U.S. at 579 (Thomas, J., dissenting) (noting the Court's "institutional inability to weigh competing concerns correctly"); cf. Nzelibe, supra note 47, at 1002-03 (adopting approach based on institutional competency that accepts greater judicial competence in cases implicating individual rights, rather than those involving foreign affairs powers without challenges based on rights claims). 
doctrine, notably Professor Franck, who argue that the political question approach undermines the rule of law which demands a role for judges in addressing constitutional questions related to the allocation of war and foreign affairs powers, must face "insuperable obstacles," as Professor Nzelibe has explained; ${ }^{111}$ notably, its incompatibility with constitutional text, structure, and history. Courts are not the exclusive interpreters of the Constitution; indeed, as Hamilton, Madison and Marshall explained in the early years of the Republic after Ratification, ${ }^{112}$ the political branches play an important role in constitutional deliberation and interpretation, ${ }^{113}$ and there are multiple provisions of the Constitution that are not amenable to constitutional adjudication in the courts (for example, a congressional determination as to what constitutes a "high crime or misdemeanor" under Article II, section 4, or whether the President has properly exercised veto powers under Article I, section 7). ${ }^{114}$ Moreover, in addition to the historical constitutional practice of judicial non-intervention in war powers controversies and the Constitution's structural design for allowing the Congress

$111 \quad$ Id. at 968 .

112 See Hamilton, supra note 20, at 58 (explaining as Pacificus that the executive's power to enforce the law necessarily implies his ability to interpret the laws first); 1 ANNALS OF CONG. 500 (Joseph Gales ed., 1789) (statement of Rep. Madison) (stating that "I beg to know, upon what principle it can be contended, that any one department draws from the Constitution greater powers than another, in marking out the limits of the powers of the several departments?"); John Marshall, Speech to the House of representatives of March 7, 1800, in 4 PAPERS OF JOHN MARSHALL at 95 (Charles F. Hobson, ed. 1998) (stating that the separation of powers would be "swallowed up by the judiciary" if judicial power extended to every question under the laws and treaties of the United States, "as it would involve almost every subject on which the executive could act.").

113 See Neal Kumar Katyal, Legislative Constitutional Interpretation, 50 DUKE L.J. 1335 (2001); Gary Lawson \& Christopher D. Moore, The Executive Power of Constitutional Interpretation, 81 IowA L. REV. 1267 (1996); Scott E. Gant, Judicial Supremacy and Nonjudicial Interpretation of the Constitution, 24 Hastings CONST. L.Q. 359 (1997); Louis Fisher, Constitutional Interpretation by Members of Congress, 63 N.C. L. REV. 707 (1985); Eugene W. Hickok, Jr., The Framers' Understanding of Constitutional Deliberation in Congress, 21 Ga. L. Rev. 217 (1986); Broughton, War Power, supra note 25 , at $719-24$. 
and President to engage in their own constitutional deliberation on the scope and nature of their respective war powers, we can point to the Constitutional Convention, at which Madison argued that the judicial power should extend only to cases of a "Judiciary Nature,"115 and at which the Framers explicitly rejected a proposed Council of Revision that would have given the judiciary a joint role in exercising veto power with the executive. ${ }^{116}$ Also, as a textual and structural matter, we know that the Framers approved the placement of certain categories of power belonging to one branch in another branch (for example, the Senate enjoys a judicial power, to try impeachment; ${ }^{117}$ the President enjoys legislative power, to return a bill and to recommend legislation to Congress ${ }^{118}$ ). Yet nowhere in Article III or elsewhere do the Framers give any legislative or executive power to the judiciary (a structural choice further reflected in the Convention's rejection of the Council of Revision).

An approach grounded in a robust political question doctrine is also sensible especially when we think about the nature of federative power theory. Locke based the federative power upon the kind of authority man had in the state of nature; whereas law could direct the exercise of executive power, federative power was not amenable to such directives, but rather relied upon the exercise of prudence and discretion ${ }^{119}$ (a notion reaffirmed by Publius and Pacificus). As the Hamdan decision foreshadows, judicial efforts to police such prudence and discretion will invariably involve the courts' own

\footnotetext{
1152 RECORDS, supra note 16 , at 430.

116 1 RECORDS, supra note 16 , at 20-21, 104-40.

$117 \quad$ U.S. Const. art I, $\S 3$.

$118 I d$. art. I, $\S 7$, art. II, $\S 3$.

119 See LocKE, supra note 1 , at 83.
} 
independent judgments about the normative propriety or acceptability of political action. This is not a judgment for politically independent courts.

But beyond these doctrinal constraints, and the problem of competence that I, too, find persuasive as a reason for robust doctrines that keep judicial review from doing mischief, I advocate normative limitations on judicial review grounded in a constitutionalist conception of institutional structure and responsibility. My contention is that the judicialization of federative power - by which I mean a model of judicial review that strictly and aggressively scrutinizes the constitutional allocation of federative power or a particular exercise of federative power - undermines the constitutional scheme for making, enforcing, and restraining American foreign policy. These arrangements are preferable to judicial review because they respect the forms of the Constitution, more consistent with the institutional structures that the Constitution envisions for the exercise of federative power. In this sense, it is disconcerting that Justice Thomas has so often spoken only for himself on this matter.

Unfortunately, Americans have grown accustomed to resolving essentially political disputes in the courts, and the courts have only encouraged this phenomenon, so much so that today the Supreme Court is viewed as yet another political body, existing to satisfy the immediate appetites of a demanding public. ${ }^{120}$ As The Deconstitutionalization of America explains, "the conviction that judicial actors are also political actors can have undesirable effects on the behavior of citizens." ${ }^{121}$ Thus, what emerges is a litigation culture that perpetually seeks out the judiciary for relief from disagreeable policies,

120 See BArrus, ET AL., supra note 3, at 112; RoBert H. Bork, THE TEMPting Of AmERICA 2 (1990). 
bypassing the complexity that accompanies coalitional politics and day-to-day policymaking. ${ }^{122}$ War and foreign affairs cases for most of our history have proven to be the exception; no areas of law and public policy have provoked such ready employment of the doctrines of justiciability, or other moments of judicial deference, as war and foreign affairs. Thoughtful scholars like Professor Franck and Dean Koh have disparagingly described this history as "judicial abdication" or "judicial tolerance;",123 I prefer to think of it as prudent circumspection, a virtuous trait for a limited and independent judiciary. But perhaps the war on terror cases foreshadow a change. I am reluctant to overstate the case: it is important to understand that none of these cases were cases about the separation of powers in any direct sense, and their holdings did not concern directly the constitutional allocation of federative power. They are, admittedly, imperfect symbols of a shifting approach. Still, the aggressiveness of the Court's review, and of its rebuke of the President's asserted constitutional role, presents an ominous sign.

The contemporary Supreme Court is all about courts. Far from prudently circumspect, this Court possesses an imperial understanding of its own role in the constitutional scheme (provoked by a citizenry that has been asking more and more of the federal government for some 60 years now). It assumes its competence (indeed, its superior judgment) in virtually all areas of political life, in ways that, as I have argued in a recent article concerning the Court's death penalty jurisprudence, signify a kind of judicial omnipotence and omniscience. ${ }^{124}$

122 See J. Richard Broughton, The Second Death of Capital Punishment, 58 FLA. L. REV. 639, 658 (2006) (hereafter Second Death).

123 See FRANCK, supra note 26, at 10; KOH, supra note 11, at 134.

124 See Broughton, Second Death, supra note 122, at 658. 
This is evident in the Court's death penalty cases, like Atkins v. Virginia ${ }^{125}$ and Roper v. Simmons, ${ }^{126}$ where the Court constitutionalized the superiority of its moral and political views on capital punishment by holding that the Eighth Amendment contemplated that "in the end, our own judgment will be brought to bear on the question of the acceptability of the death penalty. . ."127 It is also evident in the Court's recent political gerrymandering cases. Although four justices have clearly articulated a sound basis for applying the political question doctrine to claims of political gerrymandering, a majority of the Court simply is not prepared to relinquish its power to supervise perceived political inequities in the drawing of legislative districts. ${ }^{128}$

Modesty, as Judge Posner notes, is not the order of the day in this Supreme Court. $^{129}$ The war on terror cases, and the Hamdan case in particular, also suggest that judicial modesty will not prevail in cases involving war-time political decision-making, either.

The difficulty, however, goes beyond the mere unseemliness of the Court's arrogance. Aggressive judicial review of cases that implicate the allocation and exercise of federative power undermines not just the institutional role of the Court, but of our political institutions, as well. As I have previously argued, in this emerging regime, courts, rather than political institutions, become primary mediating institutions for $125 \quad 536$ U.S. 304 (2002).

126543 U.S. $551(2005)$.

$127 I$ Id. at 563 (quoting Atkins, 536 U.S. at 312)(quoting, in turn, Coker v. Georgia, 433 U.S. 584, 597 (1977)).

128 See Vieth v. Jubilirer, 541 U.S. 267 (2004); League of United Latin American Citizens v. Perry, 126 S. Ct. 2594 (2006) (Scalia, J., concurring in the judgment in part and dissenting in part).

129 Richard A. Posner, The Supreme Court, 2004 Term, Foreword: A Political Court, 119 HARV. L. REV. 31, 56 (2005). 
filtering out and moderating public passions and factious spirit. ${ }^{130}$ This kind of regime minimizes essential distance between governing institutions and the people. This distance, which the Constitution contemplates and makes real in its description of our institutions, provides the space that institutions need to fulfill their responsibilities (especially their most grave ones), space between the chaotic, often undisciplined cries of public opinion and the measured refinement of popular will through reason, rational deliberation and sober judgment. ${ }^{131}$ Leaders of the founding generation like Hamilton, Madison, and Marshall, believed that courts should be cognizant of the demands of practical governance in a republic, allowing the political departments to function free of an imprudent judiciary. ${ }^{132}$ Thus, the distance the Constitution provides for the executive is substantial (though modern practice has intolerably diminished it, too); the distance provided, indeed, mandated, for the judiciary is even greater, and is necessary to preserve not just the independence of the courts, but their circumspection, as well. Montesquieu and Publius both remind us that political liberty requires that judicial power be separate from the political powers vested in legislature and executive. ${ }^{133}$ By the same token, a regime of omnipotent judicial review also makes practical governance and the object of controlling the governed even more burdensome.

$130 \quad$ See Broughton, Second Death, supra note 122, at 660.

131 See Harvey C. MANSFIEld, AmericA's CONSTITUTIONAL Soul 16 (1991) (discussing the importance of constitutional "space"); see also BARRUS ET AL., supra note 3, at 15-17 (explaining Madison's vision for representation and practical governance based on reason).

132 See Hamilton, supra note 20, at 54 (describing limits on the judiciary in foreign relations and urging that each political branch be permitted room to fulfill its functions); see also David E. Marion, The State of the Canon in Constitutional Law: Lessons from the Jurisprudence of John Marshall, 9 WM. \& MARY BILL RTS. J. 385, 416 (2001) (explaining how Madison and Marshall recognized the importance of practical governance and sought limits on judicial intrusion).

133 See Montesqieu, supra note 6, at 157; The Federalist No. 47, at 302-03 (Clinton Rossiter, ed. 1961) (James Madison). 
Judicializing federative power diminishes the significance of the Constitution's commitment of competing foreign affairs powers to the political branches, the allocation of which Professor Yoo persuasively demonstrates in his recent scholarship. ${ }^{134}$ As I have argued elsewhere, constitutional deliberation should be encouraged in the political branches, each of which possesses an independent obligation to determine the Constitution's meaning. ${ }^{135} \quad$ The political branches will be less likely to deliberate seriously about their respective constitutional roles when there exists the prospect of judicial relief and guidance from the courts. And particularly in circumstances where (as is usually the case) it is the President whose assertion of power is challenged, aggressive judicial review will also undermine the significance of the Constitution's provision for political self-help. Congress possess three important checks on presidential overreaching: its power to fund foreign relations projects, its power to legislate (which includes investigative and oversight powers), and, often forgotten, its impeachment power. ${ }^{136}$ It can employ those checks without a permission slip from the courts.

One response may be that cases like Hamdan do not actually undermine political institutions, but empower them, at least to the extent that the decisions often inure to Congress's benefit, a la The Steel Seizure Case. But this argument overlooks the constitutional damage done to the Presidency. Judicializing federative power, even when (in fact, particularly when) it rebukes executive exercise of that power on constitutional grounds, will make the executive more cautious, more ambivalent, in Professor

\footnotetext{
$134 \quad$ See generally Yoo, supra note 11.
}

135 See Broughton, War Power, supra note 25, at 719-24. 
Mansfield's terms. ${ }^{137}$ It will deprive the executive of the energy that Publius reminded us is vital to its effectiveness. ${ }^{138}$

Moreover, specific affirmative constitutional grants of power to the President are compromised, which are necessary for effectuating the President's federative powers: the Vesting Clause and the Commander-in-Chief Clause are principal casualties, ${ }^{139}$ but one must not overlook the significance, too, of the Oath Clause. ${ }^{140}$ The constitutional Oath operates as an affirmative grant of power to the President to defend the Constitution. To be sure, other officers must also take an oath, but their oaths are not constitutionally prescribed and the Constitution says only that they must "support this Constitution." As a textual and structural matter, then, there is something significant about the fact that the President's oath is placed in the Constitution and that it requires him to "preserve, protect, and defend" the Constitution, rather than merely "support" it. The oath provides a mechanism and a source of legitimacy for the exertion of the President's energy to

137 See generally MANSFIELD, TAMING THE PRINCE, supra note 4.

138 See The FEDERALIST No. 70, at 423 (Alexander Hamilton).

139 See U.S. CONST. art II, $\S \S 1,2$; see also YOO, supra note 11, at 183-84, 272 (pointing to areas of foreign affairs that are predominantly "executive" in nature and are supported by the Vesting Clause); Prakash \& Ramsey, supra note 11, at 324-27 (arguing that the Vesting Clause allows President to act independently in foreign affairs where his actions are "executive" in nature); Eugene V. Rostow, "Once More Unto the Breach": The War Powers Resolution Revisited, 21 VAL. U. L. REV. 1, 14-15 (1986) (arguing that the vesting Clause gives President wide latitude in exercising war powers); Exercising Congress's Constitutional Power to End a War, Hearing before the Sen. Comm. on the Judiciary, $110^{\text {th }}$ Cong. (2007) (statement of Bradford Berenson) (stating that the "vesting Clause provides the President a vast reserve of implied authority to do whatever may be necessary in executing the laws and governing the nation"); but see Bradley \& Flaherty, supra note 11, at 53-59 (challenging the Vesting Clause Thesis as a basis for broad executive powers in foreign affairs).

140 U.S. CONST. art II, §1; see also Michael Stokes Paulsen, The Constitution of Necessity, 79 NOTRE DAME L. REV. 1257, 1258-59 (2004) (arguing that the Oath Clause allows the President to meet necessity to protect the Union); $c f$. Robert F. Blomquist, The Presidential Oath, the American National Interest, and a Call for Presiprudence, 73 UMKC L. REV. 1, 37-50 (2004) (summarizing the scant literature related to the presidential oath). 
safeguard the Republic, energy that is not just defensive in its nature and that, in the end, ought to promote civic virtue and decency. ${ }^{142}$

In a regime where a unitary executive's effort to preserve, protect, and defend the Constitution is subject to intense scrutiny by the courts, the president must constantly look over his shoulder for five disapproving Supreme Court justices (the prospect of which may be more daunting than 535 disapproving members of the House and Senate). Of course, this is true with any presidential action; but, again, the Constitution divides federative power between the political branches (note, it divides independent powers; each power is not "shared," but rests solely in the branch to which it is given, to resist encroachment) in ways that it does not divide other categories of power - the distribution of federative power to multiple branches is unique in our constitutional scheme - which reflects the constitutional and political distinction between domestic action and foreign affairs, where the consequences of lacking energy are more dire. The very characteristics that define the energetic executive are of special import in the domain of foreign affairs, where the president must be able to act with dispatch and secrecy. ${ }^{143}$ A judicialized

142 See THE FEDERALIST No. 70, at 423 (Alexander Hamilton) (noting that energy was essential not just to defend against attack but also for the "steady administration of the laws," the protection of property and of liberty); see also Henry P. Monaghan, The Protective Power of the Presidency, 93 Colum. L. ReV. 1, 66-70 (1993) (discussing the role of the oath as expressing the President's "protective" power).

Michael Stokes Paulsen makes a compelling case for the scope of President's duties under the Oath Clause, which includes dominant duties of constitutional interpretation. See Paulsen, supra note 140, at 1258-1260. Moreover, although he does not explicitly advocate judicial abstention or application of the political question doctrine to matters involving war and foreign affairs, Professor Paulsen argues that the President's duty under the Oath Clause suggests that "the President cannot be bound by the decisions of courts, in the sense that he must defer, no matter what." Id. at 1296. Should the President determine that necessity requires his action, then "his duty as President - his duty to the Constitution - requires that he not let a judicial decision to the contrary prevent him from performing what his duty requires." $I d$. Pursuant to this view (which is a persuasive one), the Oath could serve to counteract judicialization of the federative power, to the extent that it permits a President to avoid compliance with a judicial decision contrary to his own interpretation of his constitutional responsibilities. One wonders, however, whether political and other practical considerations (e.g., intense scrutiny and criticism from the mass media) would ever permit a modern President to do this.

See The Federalist No. 70, at 424 (Alexander Hamilton). 
federative power like the one that Hamdan portends, however, has the potential to relegate the Commander-in-Chief to service at the pleasure of the courts. Unity and energy are thereafter marginalized to the point of meaninglessness. Judicial fingerwagging at the President (of the kind we see in Hamdi and Hamdan) may seem appealing and useful at a time when the President and his foreign policy are unpopular. But it can do lasting damage to the institution and, thus, to the republic.

It is in the executive that the Constitution best balances stability and adaptability and best reflects the Lockean vision of federative power. Professor Mansfield correctly explains that our system constitutionalizes necessity in the manner of Locke. ${ }^{144}$ Accident and force cannot be removed from human affairs. ${ }^{145}$ The Constitution's genius lies, in part, in its capacity to constitute an institution that may (must) grapple with necessity, while still retaining the republican form. Both Publius and Pacificus remind us that energy is not a recipe for prerogative; ${ }^{146}$ rather, it is a kind of Aristotelian mean between weakness and unrestrained prerogative. Nor is energy in the executive incompatible with safe government. ${ }^{147}$ In this sense, at least, we can see once again how the Constitution's prescription for federative power is more Lockean than its surface allocations would suggest.

\footnotetext{
144 MANSFIELD, TAMING THE PRINCE, supra note 4, at 255.

$145 \quad I d$.

146 See, e.g., THE FEDERALIST No. 69, at 416-17 (Alexander Hamilton) (distinguishing the President from the King, who enjoyed the prerogative, and noting specifically that use of the veto would not amount to general prerogative); Hamilton, supra note 20, at 57 (conceding that Congress may employ its own powers).

See The Federalist No. 70, at 423-31 (Alexander Hamilton).
} 
Another response may be that an absence of judicial oversight will weaken Congress, so much so as to make its federative powers meaningless, or, as Justice O'Connor seemed concerned in Hamdi, judicial deference would effectively place federative powers solely within a single branch. But why must this be so?

This argument assumes that Congress needs the prospect of judicial relief to defend its own constitutional powers. But as I have explained already, those powers exist independently of any judicial bolstering; lacking the political will or fortitude to employ them is not the same as not having them in the first place. ${ }^{148}$ This argument also assumes, again wrongly I think, that federative power is a kind of zero-sum game, where we must choose between a weak Congress and a strong executive, or a weak executive and a strong Congress. By implementing a design where the political branches are empowered to struggle with one another and deliberate seriously about the exercise of American military and diplomatic authority, the Constitution contemplates that we can have a strong Congress and a strong executive in foreign affairs. It contemplates that ambition will be made to counteract ambition. ${ }^{149}$ If the Framers had meant to adopt a purely and formally Lockean version of federative power, they would not have given Congress the constitutional tools to safeguard its own prerogatives in war and foreign policy. The War Powers Resolution is the modern Congress's most dominant assertion of its prerogatives. Moreover, it is particularly notable that the $110^{\text {th }}$ Congress has taken action to further undermine the notion that the Republic's dominant branch needs the support of the courts to protect its constitutional prerogatives in the area of federative

\footnotetext{
148 See YoO, supra note 11 , at 159. 
power. Multiple bills and non-binding resolutions have been introduced to limits President Bush's efforts to send more military troops to Iraq in an effort to stem the tide of violence there and better enable Iraqi forces to secure their communities. ${ }^{150}$ The Senate Judiciary Committee also held a hearing to explore the nature and scope of its war powers. ${ }^{151}$ Whether these actions eventually result in binding legal authority, or produce an actual conflict with the Executive, or are even politically or constitutionally desirable, is another matter entirely. They reflect at the very least an institutional interest in (indeed, a capacity for) asserting legislative prerogatives in the war powers arena, further ratifying the wisdom that the Constitution contemplates conflict and competition between the political branches free from a judicialized federative power.

Consequently, judicialization does damage to both the Lockean and un-Lockean forms of the constitutional structure.

\section{CONCLUSION}

Those who argue that the second President Bush has asserted an unprecedented view of executive authority overlook much history, and its lessons. Our political and constitutional history is littered, both in theory and in practice, with competing arguments

150 See, e.g., Sen. Con. Res. 2, $110^{\text {th }}$ Cong. (introduced Jan. 17, 2007) (sponsored by Sen. Biden, expressing a bipartisan resolution in Iraq); S. $121,110^{\text {th }}$ Cong. (introduced Jan. 4, 2007) (sponsored by Sen. Feingold, providing for redeployment of United States forces from Iraq); S. 433, $110^{\text {th }}$ Congress (introduced Jan. 30, 2007) (sponsored by Sen. Obama, expressing United States policy for Iraq); see also Sen. Res. 39, $110^{\text {th }}$ Cong. (introduced Jan. 24, 2007) (sponsored by Sen. Byrd, expressing sense of the Senate that Congress approve any offensive military action by United States against any other nation). the Judiciary, $110^{\text {th }}$ Cong. (2007); see also id. (statement of Sen. Feingold) (stating "[t]he President had chosen to ignore [the message of voters in November 2006]. So it is up to Congress to act."); id. (statement of Louis Fisher) (discussing various constitutional and political tools of Congress possesses and concluding that "[i]n a democratic republic, [the decision to commit military forces] legitimately and constitutionally resides in Congress."). 
about the scope of presidential powers. And some of our most beloved Presidents were ones who took particularly robust views of their Article II authority, despite the unpopularity of their actions or claims that they had acted without precedent. This is not to justify any particular foreign policy decision by the current President or any other occupant of the Office. It is, rather, to suggest that his view of presidential power would not have been unfamiliar to other Presidents who faced national emergencies and grave threats in the international system; those "tides" in the "affairs of men" of which Jay speaks in Federalist \#64. That a politically-friendly Congress has, as some feel, failed to assert its own prerogatives is hardly the fault of the President, and, to be sure, the President's assertion of his own prerogatives does not become "extraordinary" or "unprecedented" merely because the counterexample is a Congress that either agrees with the President or, as in some historical instances, still in search of a spine donor.

But in order to meaningfully employ a scheme in which congressional and executive federative powers are simultaneously robust but not encroaching, we must, rather than seek solace from the courts, take seriously the formal institutional arrangements that the Constitution provides. The forms of the Constitution help us secure competent government, safe government. When we value the convenience of judicial bypass above form, it often becomes easier for one branch to encroach, or to at least justify the encroachment, something about which the Framers were primarily concerned. Distance was, for them, a structural virtue. Over time, the offended branch becomes too weak to defend its constitutional prerogatives. When we rely upon the forms of the Constitution, however, we see a scheme for the robust exercise of constitutional prerogatives by the political branches that also resists, or at least checks, encroachments. 
That scheme is particularly dynamic in the field of federative power. Judicializing federative power, however, undermines the formal constitutional design and, ultimately, marginalizes political authority to address and respond to the harsh realities and necessities that accompany the conduct of actors in the international arena. Circumscribing judicial review of the political branches, and particularly a Lockean executive, may seem dangerous. It is - but so is an omnipotent judiciary . . perhaps moreso. 